\title{
MODELING DYNAMIC ADSORPTION ISOTHERMS AND THERMODYNAMIC PROPERTIES OF SPECIALTY GROUND ROASTED-COFFEE (Coffea arabica L.)
}

\author{
Gentil Andres Collazos-Escobar ${ }^{1}$, Nelson Gutiérrez-Guzmán², Henry A. Váquiro-Herrera ${ }^{3}$
}

(Received: November 16, 2018; accepted: March 18, 2019)

\begin{abstract}
Specialty coffee is highly differentiated product because of its sensorial attributes: aroma, body and brand reputation. In specialized markets, these products are highly valued, and sometimes up to six times their commercial value is paid. Thus, it is essential to preserve their freshness. Sorption isotherms are necessary for determining and studying water sorption changes in specialty coffee during storage. This study aimed to determine the adsorption isotherms of specialty ground roasted-coffee at temperatures of $25^{\circ} \mathrm{C}, 30^{\circ} \mathrm{C}$ and $40^{\circ} \mathrm{C}$ and water activities between 0.1 and 0.8 using the dynamic dewpoint method (DDI). The experiment sorption data were modeled using 12 different equations with non-linear regression to represent the dependence of the equilibrium moisture content with both water activity and temperature. In addition, the thermodynamic properties were determined with the experiment adsorption data. The results showed that type III isotherms were obtained according to the Brunauer classification, and the Weibull equation satisfactorily modeled the effect of the temperature on the hygroscopic equilibrium in the specialty ground roasted-coffee. The results of thermodynamic analysis showed that the net isosteric heat of adsorption and Gibbs free energy decreased as the equilibrium moisture content increased, indicating the amount of energy released, a strong bond energy between water molecules in the product components and spontaneity in the adsorption process. The entropy of the adsorption increased with the moisture content, leading to product stability conditions during storage; it was possible to conclude that to guarantee the stability of high quality, ground, roasted coffee should store in environments where the water activity does not exceed 0.5 at temperatures between $25^{\circ} \mathrm{C}$ and $40{ }^{\circ} \mathrm{C}$. The results were similar to those reported for the roasted and ground coffee of others cultivars.
\end{abstract}

Index terms: Water activity, equilibrium moisture content, hygroscopicity.

\section{MODELAGEM DE ISOTERMAS DE ADSORÇÃO DINÂMICA E PROPRIEDADES TERMODINÂMICAS DE CAFÉ ESPECIAL TORRADO E MOÍDO (Coffea arabica L.)}

RESUMO: O café especial é um produto altamente diferenciado por seus atributos sensoriais: aroma, corpo e reputação da marca. Nos mercados especializados, estes produtos são altamente valorizados e as vezes podem ser pagados em até seis vezes seu valor comercial. Deste modo, é essencial preservar seu frescor. As isotermas de sorção são necessárias para a determinação e o estudo das mudanças da sorção de água no café especial durante o armazenamento. O objetivo deste trabalho foi determinar as isotermas de adsorção de café especial torrado e moído para temperaturas de $25^{\circ} \mathrm{C}, 30^{\circ} \mathrm{C}$ e $40{ }^{\circ} \mathrm{C}$ e atividades de água entre 0.1 e 0.8 usando o método dinâmico de ponto de orvalho (DDI). Os dados de sorção experimentais foram modelados usando 12 equações diferentes através de regressão não linear, para representar a dependência do teor de água de equilíbrio com a atividade de água e a temperatura. Adicionalmente, foram determinadas as propriedades termodinâmicas a partir dos dados experimentais de adsorção. Os resultados mostraram que foram obtidas isotermas tipo III, de acordo com a classificação Brunauer e a equação Weibull modelou satisfatoriamente o efeito da temperatura sobre o equilíbrio higroscópico em café especial torrado e moído. Os resultados da análise termodinâmica mostraram que o calor isostérico líquido de adsorção e a energia livre de Gibbs diminuíram com o aumento do teor de água de equilíbrio, indicando a quantidade de energia liberada, uma forte energia de ligação entre as moléculas de água nos componentes do produto e a espontaneidade no processo de adsorção. A entropia de adsorção aumentou com o teor de água, levando a condições de estabilidade do produto durante o armazenamento; foi possível concluir que para garantir a estabilidade do café torrado e moído de alta qualidade deve-se armazenar em ambientes onde a atividade de água não exceda de 0.5 para temperaturas entre $25^{\circ} \mathrm{C}$ e $40^{\circ} \mathrm{C}$. Os resultados foram semelhantes aos relatados para café torrado e moído de outras cultivares.

Termos para indexação: Atividade de água, teor de água de equilíbrio, higroscopicidade.

\section{INTRODUCTION}

"Coffee is an ancient beverage that has a relationship with the development of human civilization" (TSAI et al., 2016), and is widely consumed throughout the world because of its unique sensory properties and physiological effects (KREUML et al., 2013). It is considered one of the most important products in the world because of income from exportation and industrialization (CORRÊA et al., 2010). The specialty coffee is generally defined by an excellent and unique flavor (PICCINO et al., 2014), it has become a highly differentiated product, in terms of sensorial attributes (aroma, body) and brand reputation as Colombian coffee (ÖZDESTAN et al., 2013),

\footnotetext{
${ }^{1,2}$ Centro Surcolombiano de Investigación en Café CESURCAFE/Universidad Surcolombiana - Departamento de Ingeniería Agrícola - Cx.P. 410001 - Neiva - Colombia - gentilcollazosescobar09@gmail.com,ngutierrezg@usco.edu.co ${ }^{3}$ Facultad de Ingeniería Agronómica - Universidad del Tolima - Ibagué-Tolima - Colombia - havaquiro@ut.edu.co
} 
this product is generally destined to specialized markets where the prices reached can be up to six times the value of a traditional coffee (TAPIERO et al., 2017).

Coffee is a highly hygroscopic material and can readily take up moisture when exposed to the environment during storage (IACCHERI et al., 2015); this condition may affect coffee freshness. For preserving desirable sensory quality, it is necessary to guarantee the storage conditions (BORÉM et al., 2013). For the proper handling of ground roasted-coffee it is necessary to know, among other properties, the water sorption isotherms, which describe the relationship between the equilibrium moisture content and the water activity at constant temperature and pressure (BASTIOĞLU et al., 2017). There is a large numbers of sorption equations for the characterization of the water sorption behavior of foods (MOUSA et al., 2012), such models can be theoretical, empirical or semi-empirical equations. Because of the complex nature of food matrices, there is not a unique model to entirely describe agri-food products (BON et al., 2012); therefore, is necessary to validate the best model for both the material and the environment conditions using experiment data.

Traditionally, sorption isotherms in coffee have been generated using the static method. This method has disadvantages such as long periods to reach product equilibrium, difficulty in obtaining conclusive and precise measurements, large samples and great effort on the part of researchers to obtain weight measurements when seeking balance (SCHMIDT \& LEE, 2012). These drawbacks have been overcome with the development of the dynamic in the sorption of water vapor, in particular the dynamic dewpoint isotherm method (IACCHERI et al., 2015). This method offers highly available experiment points, broad working conditions and high precision, thus eliminating the disturbances associated with the manipulation of samples and the possible mass transfer phenomenon with the environment where the experiment is carried out (SCHMIDT \& LEE, 2012). IACCHERI et al. (2015) have employed the DDI method to obtain sorption isotherms of green coffee and roasted coffee, however, they have not included the temperature effect in the sorption isotherms, moreover, in the literature has not been reported sorption isotherms specialty coffee.

Knowledge of the temperature effect on sorption isotherms is of great importance since foods can be exposed to a wide range of temperatures during storage and processing (EIM et al., 2011). By observing the effect of temperature on sorption isotherms, it is possible to determine the thermodynamic properties of agricultural products and obtain helpful information with respect to energy changes in the system (VILLAVÉLEZ et al., 2012); thus, thermodynamic properties are a key resource that can reveal the effect of water activity on storage (OLIVEIRA et al., 2016).

The net isosteric heat of sorption represents the total energy available to do work (MARTÍNEZLAS HERAS et al., 2014) and provides important information on the energy requirement for different processes and the state of water molecules in food (TADAPANENI et al., 2017). Gibbs free energy represents the spontaneity of water gain and loss processes between a product and the environment (TEIXEIRA et al., 2018), and sorption entropy (differential entropy) indicates the number of available sorption sites at a specific energy level and can be related to the attraction-repulsive forces in a system (YOGENDRARAJAH et al., 2015); it also indicates the degree of order of the water molecules in a product (PROKOPIUK et al., 2010).

Because of the importance of understanding the hygroscopicity of Colombian specialty ground roasted-coffee from Huila region and its dependence on water activity and temperature, the objective of the present study was to determine the adsorption isotherms of specialty ground roasted-coffee at $25{ }^{\circ} \mathrm{C}, 30{ }^{\circ} \mathrm{C}$ and $40{ }^{\circ} \mathrm{C}$, and water activities between 0.1 and 0.8 using the dynamic dew point method, to evaluate the ability of different models in describing the adsorption isotherms and to determine the net isosteric heat of adsorption, Gibbs free energy and adsorption entropy with the purpose of defining the best storage conditions for this product.

\section{MATERIALS AND METHODS}

\subsection{Coffee samples}

Nine specialty coffee samples of variety Colombia, Castillo and Caturra (Coffee arabica L.), from different farmers of Huila region of Colombia, that were processed by the wet method, underwent sensory analysis with the Specialty Coffee Association of America (SCAA) methodology (SCAA, 2015) in the South Colombian Coffee Research Center (CESURCAFÉ) by four expert panelists (DI DONFRANCESCO et al., 2014), cup scores were between 84 to 86.5 the samples were considered as high-quality specialty coffee. 
The coffee beans were roasted at $180 \pm 2$ ${ }^{\circ} \mathrm{C}$ during $8 \pm 2 \mathrm{~min}$, in a laboratory with a TC150R (Quantik, Colombia), at medium roast $\left(21.0<L^{*}<24.2\right)$ (WEI \& TANOKURA, 2015). After roasting, the coffee samples were ground separately to medium size particle (particles retained in a \#20 standard sieve; hole diameter of $0.85 \mathrm{~mm}$ ), using a Bunn G3HD milling device (Bunn Coffee Mill, Springfield, II. USA).

\subsection{Experiment determination of the adsorption isotherms}

For the development of the dynamic dewpoint method (DDI), 2 to $3 \mathrm{~g}$ of specialty ground roasted-coffee were placed inside a vapor sorption analyzer (VSAAqualab Decagon Device, Inc. Pullman, WA, USA). The $a_{w}$ range for the measurements was defined between 0.1 and 0.8 at temperatures of $25^{\circ} \mathrm{C}, 30^{\circ} \mathrm{C}$ and $40{ }^{\circ} \mathrm{C}$, and the $a_{w}$ interval was 0.01 for the adsorption with an air flow rate of $100 \mathrm{ml} \cdot \mathrm{min}^{-1}$. The initial moisture content of the samples was made with a moisture tester (Kett PM-450, Science of Sensing, Japan). All tests were performed in triplicate for each temperature.

\subsection{Modeling the adsorption isotherms}

The adsorption isotherms of the ground, roasted specialty coffee was represented mathematically using the twelve models shown in Table 1 , where $X_{e}$ is the equilibrium moisture content ( $\%$, dry basis), $a_{w}$ is the water activity, $A, B$ and $C$ are the GAB model parameters (CORREA et al., 2010), $T$ is the absolute temperature $(\mathrm{K})$ and $b_{i}$ is the empirical model parameters.

\subsubsection{Parameter estimation and statistical analysis}

The non-linear regression analysis Matlab ${ }^{\circledR}$ R2016b (The MathWorks Inc., Natick, MA, USA) to identify the model parameters and calculate the $95 \%$ confidence intervals of the parameters. The adjusted determination coefficient $\left(R_{a d j}^{2}\right)$ and the root mean square error (RMSE) were used as goodness-of-fit statistics. High values of $R^{2}{ }_{a d j} \geq 0.9$ and low values of RMSE (lower than $10 \%$ d.b.) are considered to be a reasonable fit (BASTIOĞLU et al., 2017).

\subsection{Thermodynamic properties}

The thermodynamic properties were calculated from the experiment data of moisture adsorption isotherms. The net isosteric heat of adsorption can be computed using the ClausiusClapeyron equation (Eq. 13), from the slope of the plot of $\ln \left(a_{w}\right)$ versus 1/T (DOMIAN et al., 2018; TADAPANENI et al., 2017). The net isosteric heat of sorption $\left(q_{s n}\right)$ can be calculated by integrating Eq. 13 between two temperatures (Eq. 14). In the literature also has been reported the Riedel equation (Eq. 15) to describe the influence of temperature on water activity. Thus, another expression to estimate net isosteric heat of sorption may be considered (Eq. 16) by combining Eqs. (14) and (15) (GARCÍA-PÉREZ et al., 2008).

$$
\begin{gathered}
q_{s n}=-R\left[\frac{\partial\left(\ln a_{w}\right)}{\partial\left(\frac{1}{T}\right)}\right]_{X_{e}} \\
q_{s n}=R\left[\frac{T_{1} T_{2}}{T_{2}-T_{1}} \ln \frac{a_{w_{2}}}{a_{w_{1}}}\right]
\end{gathered}
$$

$$
\ln \left(\frac{a_{w_{2}}}{a_{w_{1}}}\right)=A_{r} \exp \left(-B_{r} X_{e}\right)\left(\frac{1}{T_{1}}-\frac{1}{T_{2}}\right)
$$

$$
q_{s n}=C_{r} \exp \left(-B_{r} X_{e}\right)
$$

Where $R$ is the universal gas constant for water vapor $\left(8.314 \times 10^{-3} \mathrm{~kJ} \cdot \mathrm{mol}^{-1} \cdot \mathrm{K}^{-1}\right), A_{r}$, $B_{r}$ are constants of the Riedel equation and $C_{r}$ being $A_{r} \cdot \mathrm{R}$. Gibbs free energy $(\Delta \mathrm{G})$ was defined according to Eq. (17); where the changes of free energy were positive for desorption and negative for the adsorption (BAPTESTINI et al., 2017). The entropy of adsorption $(\Delta \mathrm{S})$ was calculated with Eq. (18).

$$
\Delta G= \pm R T \ln \left(a_{w}\right)
$$

$$
\Delta S=\frac{q_{s n}-\Delta G}{T}
$$


TABLE 1 - Mathematical models used to represent the ground roasted-coffee isotherms*

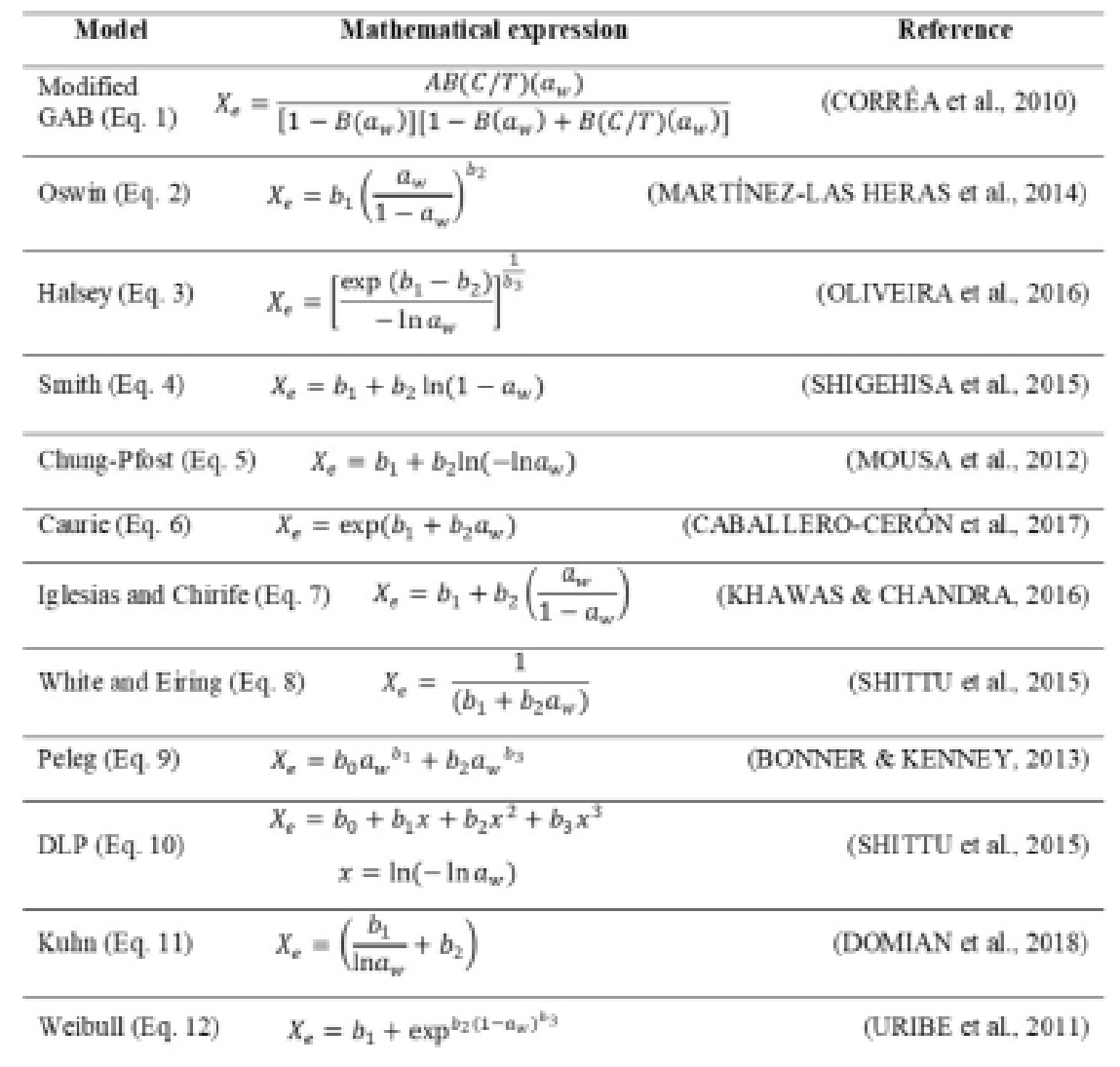

*In all cases, a linear dependence of temperature on the bi parameter was considered $\left(b_{i} T+b_{i .1}\right)$

\section{RESULTS AND DISCUSSION}

Table 2 shows the ten mathematical models with the best fit results and others models, considering the effect of temperature on the isotherms of adsorption.

The Weibull model may be the best equation to represent all of the DDI experiment data because it reached the highest $R_{a d j}^{2}(0.975)$ and the lowest RMSE $(0.389 \%$ d.b.) values. In addition, the confidence intervals showed that all parameters of the model were statistically significant at a confidence level of $95 \%$, indicating a good fit for practical purposes (BAPTESTINI et al., 2017). The others nine mathematical models (GAB, Halsey, Iglesias and Chirife, White and Eiring, Peleg, DLP, Kuhn, Oswin, and Caurie) resulted in values of the $R^{2}$ adj coefficient below 0.975 and of the RMSE higher than $0.389 \%$ d.b., with respect to those obtained by the Weibull model however, the models showed a well goodness of fit and parameters statistically significant (95\%), these models have been used in others food product and they have obtained an excellent goodness of fit: YOGENDRARAJAH et al. (2015) in adsorption isotherms of whole black peppercorns (Peleg, Oswin, and DLP), OLIVEIRA et al. (2016) in roasted coffee.

The Smith and Chung-Pfost models did not showed a good fit better than other models due to the lower $R_{a d j}^{2}<0.9$ and the highest $R M S E$ values Table 2, and should not be considered for representing the adsorption process of specialty ground roasted-coffee.

Our results were different from those mentioned above, because the number of experiment data with DDI method, with often $>75$ (SCHMIDT \& LEE, 2012). Thus, the Weibull model represented better the hygroscopic behavior with great ability for describing the adsorption process and it was the best option for the prediction of the equilibrium moisture content of specialty ground roasted-coffee under the studied conditions. 
TABLE 2 - Estimated model parameters and statistical results.

\begin{tabular}{|c|c|c|c|c|}
\hline Models & Parameters & Confidence Intervals $95 \%$ & $\boldsymbol{R}_{a d j}^{2}$ & $\begin{array}{c}\text { RMSE } \\
\text { (\% d.b.) }\end{array}$ \\
\hline $\begin{array}{c}\text { Modified } \\
\text { GAB }\end{array}$ & $\begin{array}{l}C=1050 \mathrm{~K}^{-1} \\
B=1.00 \\
A=2.213 \% \text { d.b. }\end{array}$ & $\begin{array}{l}{[905.9,1194]} \\
{[\text { Fixed at bound }]} \\
{[2.163,2.263]}\end{array}$ & 0.916 & 0.724 \\
\hline Halsey & $\begin{array}{l}b_{3}=0.939 \\
b_{2}=8.980 \times 10^{-3} \mathrm{~K}^{-1} \\
b_{1}=3.336 \times 10^{-3} \mathrm{~K}^{-1}\end{array}$ & $\begin{array}{l}{[0.922,0.955]} \\
{\left[8.945 \times 10^{-3}, 9.014 \times 10^{-3}\right]} \\
{\left[3.323 \times 10^{-3}, 3.348 \times 10^{-3}\right]}\end{array}$ & 0.956 & 0.521 \\
\hline Iglesias and Chirife & $\begin{array}{l}b_{2.1}=-0.086 \\
b_{2}=3.620 \times 10^{-4} \mathrm{~K}^{-1} \\
b_{1}=2.936 \times 10^{-5} \mathrm{~K}^{-1}\end{array}$ & $\begin{array}{l}{[-0.098,-0.074]} \\
{\left[3.239 \times 10^{-4}, 4.014 \times 10^{-4}\right]} \\
{\left[2.739 \times 10^{-5}, 3.133 \times 10^{-5}\right]} \\
\end{array}$ & 0.958 & 0.509 \\
\hline White and Eiring & $\begin{array}{l}b_{2.1}=-480.8 \\
b_{2}=1.320 \mathrm{~K}^{-1} \\
b_{1.1}=405.6 \\
b_{1}=-1.097 \mathrm{~K}^{-1}\end{array}$ & $\begin{array}{l}{[-546.0,-415.6]} \\
{[1.108,1.532]} \\
{[356.2,455]} \\
{[-1.259,-0.937]} \\
\end{array}$ & 0.969 & 0.437 \\
\hline Peleg & $\begin{array}{l}b_{3}=0.279 \\
b_{2}=9.475 \times 10^{-5} \mathrm{~K}^{-1} \\
b_{1}=5.701 \\
b_{0.1}=-0.953 \\
b_{0}=4.118 \times 10^{-3} \mathrm{~K}^{-1}\end{array}$ & $\begin{array}{l}{[0.209,0.348]} \\
{\left[8.587 \times 10^{-5}, 1.036 \times 10^{-4}\right]} \\
{[5.401,6.002]} \\
{[-1.144,-0.763]} \\
{\left[3.467 \times 10^{-3}, 4.77 \times 10^{-3}\right]} \\
\end{array}$ & 0.970 & 0.427 \\
\hline DLP & $\begin{array}{l}b_{3}=-0.011 \mathrm{~K}^{-1} \\
b_{2.1}=-0.145 \\
b_{2}=5.247 \times 10^{-4} \mathrm{~K}^{-1} \\
b_{1}=-0.013 \\
b_{0}=7.414 \times 10^{-5} \mathrm{~K}^{-1}\end{array}$ & $\begin{array}{l}{[-0.013,-0.010]} \\
{[-0.167,-0.122]} \\
{\left[4.506 \times 10^{-4}, 5.987 \times 10^{-4}\right]} \\
{[-0.014,-0.012]} \\
{\left[7.235 \times 10^{-5}, 7.593 \times 10^{-5}\right]} \\
\end{array}$ & 0.966 & 0.46 \\
\hline Kunh & $\begin{array}{l}b_{1.1}=0.053 \\
b_{1}=-2.523 \times 10^{-4} \mathrm{~K}^{-1}\end{array}$ & $\begin{array}{l}{[0.043,0.063]} \\
{\left[-2.856 \times 10^{-4},-2.191 \times 10^{-4}\right]}\end{array}$ & 0.953 & 0.54 \\
\hline Weibull & $\begin{array}{l}b_{3.1}=3.354 \\
b_{3}=-8.843 \times 10^{-3} \mathrm{~K}^{-1} \\
b_{2.1}=-42.90 \\
b_{2}=0.118 \mathrm{~K}^{-1} \\
b_{1.1}=0.115 \\
b_{1}=-3.308 \times 10^{-4} \mathrm{~K}^{-1}\end{array}$ & $\begin{array}{l}{[2.699,4.008]} \\
{\left[-10.980 \times 10^{-3},-6.706 \times 10^{-3}\right]} \\
{[-49.66,-36.15]} \\
{[0.096,0.140]} \\
{[0.075,0.155]} \\
{\left[-4.629 \times 10^{-4},-1.987 \times 10^{-4}\right]}\end{array}$ & 0.975 & 0.389 \\
\hline Oswin & $\begin{array}{l}b_{2}=0.823 \\
b_{1.1}=-0.077 \\
b_{1}=3.645 \times 10^{-4} \mathrm{~K}^{-1}\end{array}$ & $\begin{array}{l}{[0.804,0.841]} \\
{[-0.094,-0.06]} \\
{\left[3.078 \times 10^{-4}, 4.213 \times 10^{-4}\right]}\end{array}$ & 0.934 & 0.641 \\
\hline Smith & $\begin{array}{l}b_{2.1}=0.1346 \\
b_{2}=-6.274 \times 10^{-4} \mathrm{~K}^{-1} \\
b_{1}=-4.944 \times 10^{-6} \mathrm{~K}^{-1}\end{array}$ & $\begin{array}{l}{[0.095,0.173]} \\
{\left[-7.552 \times 10^{-4},-4.996 \times 10^{-4}\right]} \\
{\left[-9.188 \times 10^{-6},-6.997 \times 10^{-6}\right]}\end{array}$ & 0.878 & 0.873 \\
\hline Chung-Pfost & $\begin{array}{l}b_{2.1}=0.161 \\
b_{2}=-6.499 \times 10^{-4} \mathrm{~K}^{-1} \\
b_{1}=8.914 \times 10^{-5} \mathrm{~K}^{-1}\end{array}$ & $\begin{array}{l}{[0.103,0.22]} \\
{\left[-8.427 \times 10^{-4},-4.572 \times 10^{-4}\right]} \\
{\left[8.61 \times 10^{-5}, 9.219 \times 10^{-5}\right]}\end{array}$ & 0.804 & 1.11 \\
\hline Caurie & $\begin{array}{l}b_{2}=3.664 \\
b_{1.1}=-8.632 \\
b_{1}=0.011 \mathrm{~K}^{-1}\end{array}$ & $\begin{array}{l}{[3.573,3.755]} \\
{[-9.172,-8.093]} \\
{\left[9.361 \times 10^{-3}, 0.013\right]} \\
\end{array}$ & 0.926 & 0.68 \\
\hline
\end{tabular}


The figure 1 shows the experiment values and the estimations obtained with the Weibull model at $25^{\circ} \mathrm{C}, 30^{\circ} \mathrm{C}$ and $40^{\circ} \mathrm{C}$.

The resulting DDI isotherms were type III according to the Brunauer classification (BRUNAUER et al., 1940). Similar isotherm forms were reported in roasted coffee by BAPTESTINI et al. (2017); OLIVEIRA et al. (2016) and IACCHERI et al. (2015). According to LABUZA \& ALTUNAKAR (2007), type III isotherms represent food systems composed mainly of crystalline components, such as sugars and salt. Thus, the type III isotherms obtained may have been due to reactions in the coffee roasting process, where the water-soluble polysaccharides were formed after roasting (WEI \& TANOKURA, 2015). The values of equilibrium moisture content as function of water activity at $25{ }^{\circ} \mathrm{C}$ were similar to those reported by IACCHERI et al. (2015) in DDI isotherms of roasted coffee beans and HERMAN et al. (2018) in fermented cocoa beans. As can seen in figure 1, there were not statistically significant differences (95\%) from adsorption isotherms at 25, 30 and 40 ${ }^{\circ} \mathrm{C}$ in the range of water activity between $0.1-0.6$ as confirmed by analysis of variance, however, in $a_{w}>$ 0.6 the effect of the temperature on the adsorption isotherm at $40{ }^{\circ} \mathrm{C}$ presented statistically significant differences in respect to 25 and $30^{\circ} \mathrm{C}$ and did not differ in the last water activity value (0.8). As can be observed, at the constant temperature, the equilibrium moisture content of the specialty, ground roastedcoffee increased with $a_{w}$; however, at a constant $a_{w}$, the equilibrium moisture content increased with temperature, indicating that the specialty, ground roasted-coffee is more hygroscopic. This trend was reported by EIM et al. (2011) in carrots; the authors explained that this behavior was due to the dissolution of sugar, which results in complete leaching of sugar in solution, a change of the crystalline structure of sugar to the amorphous state and an increase in the number of sorption sites upon swelling of biopolymers. The similar effect has been reported by ČERVENKA et al. (2015) in roasted yerba mate.

For thermodynamic properties, VILLAVÉLEZ et al. (2012) stated that, during adsorption, $\Delta S$ will be negative because the adsorbate-sorbate system becomes ordered upon adsorption and loses degrees of freedom. If $\Delta G$ is less than zero, $q_{s n}$ will have to be negative and, thus, adsorption will be exothermic. Otherwise, desorption will be endothermic.

Figure 2 shows the variation of the net isosteric heat of adsorption with the equilibrium moisture content.

The net isosteric heat of adsorption (Figure 2) decreased as the water content increased. This could be related to the amount of energy released $\left(-q_{s n}\right)$ by the adsorption of water in the product. The negative values of differential enthalpy of adsorption have been reported by OLIVEIRA et al. (2016) in roasted coffee and PROKOPIUK et al. (2010) in algarroba pods. The results of the net isosteric heat of adsorption calculated using the Riedel equation are shown in Table 3.

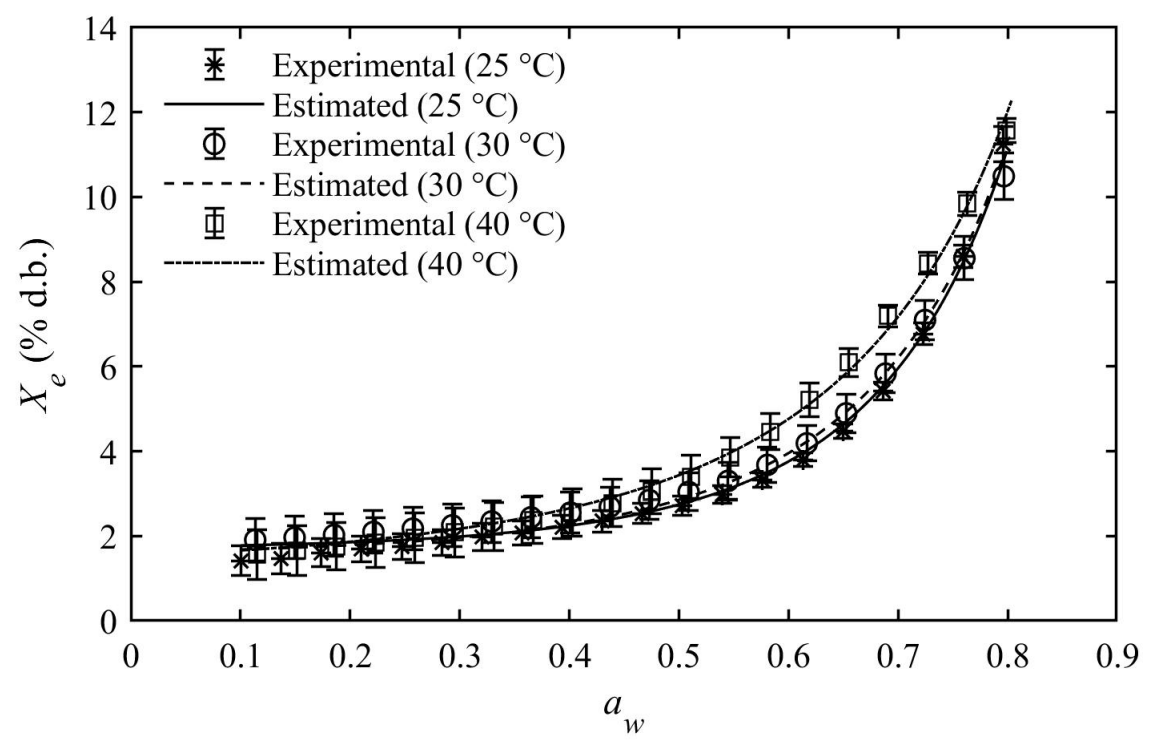

FIGURE 1 - Experiment adsorption isotherms and estimations using the Weibull model for the specialty, ground roasted-coffee at $25^{\circ} \mathrm{C}, 30^{\circ} \mathrm{C}$ and $40{ }^{\circ} \mathrm{C}$. 


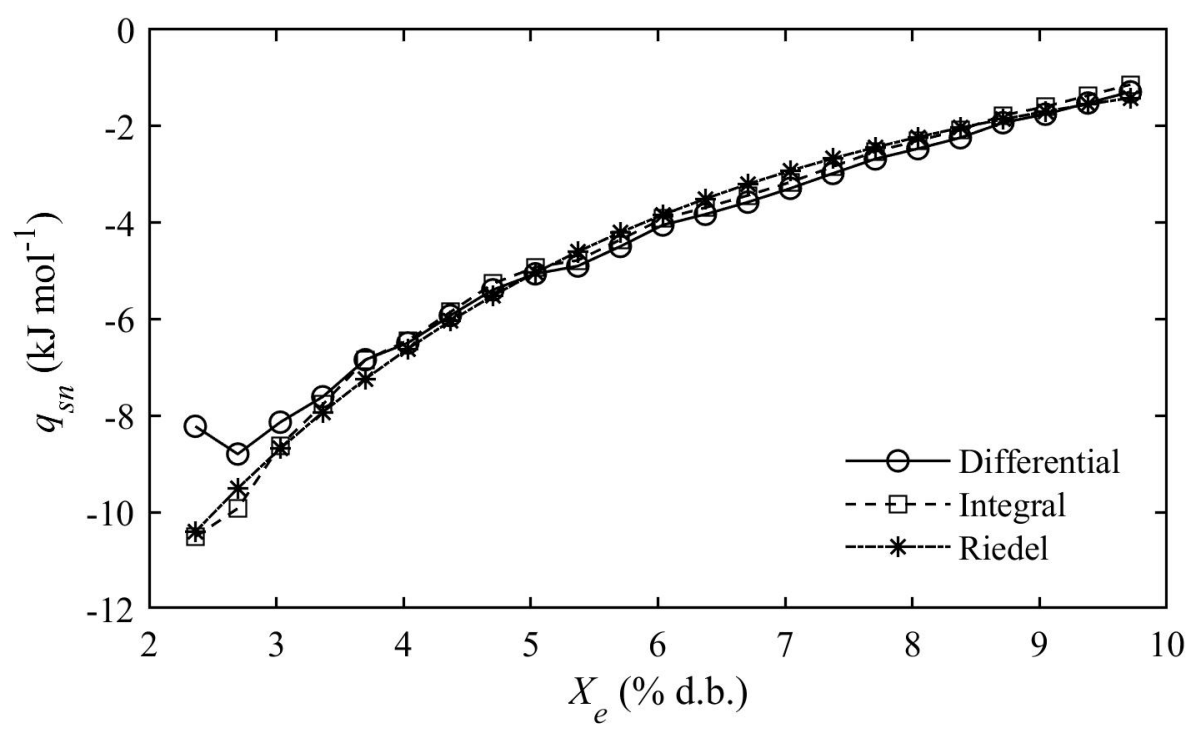

FIGURE 2 - Net isosteric heat of adsorption of the ground, roasted-coffee at $25^{\circ} \mathrm{C}, 30^{\circ} \mathrm{C}$ and $40^{\circ} \mathrm{C}$ as a function of the equilibrium moisture content

TABLE 3 - Estimation of the net isosteric heat of adsorption with the Riedel equation.

\begin{tabular}{cccc}
\hline Parameters & $\mathbf{9 5 \%}$ Confidence Intervals & $\boldsymbol{R}^{2}{ }_{a d j}$ & $\begin{array}{c}\boldsymbol{R M S E} \\
\text { (\% d.b. })\end{array}$ \\
\hline$A_{r}=-2376$ & {$[-2484,-2268]$} & 0.994 & 0.4 \\
$B_{r}=27.13$ & {$[26.05,28.21]$} & & \\
\hline
\end{tabular}

The Riedel equation satisfactorily represented the net isosteric heat of adsorption because it reached a high value for the $R^{2}$ coefficient, 0.994, and RMSE was the same at 0.4 $\%$ d.b. In addition, the confidence intervals showed that the parameters of the model were statistically significant at a confidence level of $95 \%$. This equation can be used to predict the net isosteric heat of adsorption as a function of the equilibrium moisture content.

The Gibbs free energy of the ground roasted-coffee is presented in Figure 3.

Gibbs free energy is known as an indicator of the affinity between the food sorbent and water (BASTIOĞLU et al., 2017). Changes in Gibbs free energy during water sorption between the product and the environment can be defined as the energy required to transfer water molecules from the vapor state to a solid surface, or vice versa (TEIXEIRA et al., 2018). This is the amount of work generated by the system during the adsorption process (BAPTESTINI et al., 2017).

Figure 3 presents the negative change in the $\Delta G$ with the water content, indicating the typical behavior of an exergonic reaction, which does not require the addition of energy from the environment surrounding the product for the reaction to occur, that is, the reaction is spontaneous (OLIVEIRA et al., 2016). Similar results have been reported by OLIVEIRA et al. (2016) for roasted coffee grain and other agricultural products, such as algarroba pods (PROKOPIUK et al. 2010), whole black peppercorns (YOGENDRARAJAH et al. 2015), passion fruit seeds (FERREIRA DE SOUZA et al. 2014), and pineapple pulp powder (VIGANÓ et al. 2012). Since $\Delta G$ was close to 0 as the moisture content increased, it is possible to conclude that there will be fewer sites available for sorption at higher water content levels (CANO-HIGUITA et al., 2015).

The figure 4 shows the variation of the entropy of adsorption, which represents the change in the order or disorder after water molecules are adsorbed by the system at the same hydration level (FERREIRA DE SOUZA et al., 2014; BASTIOĞLU et al., 2017). It can be observed that the entropy of adsorption increased with the increase in the equilibrium moisture content. 


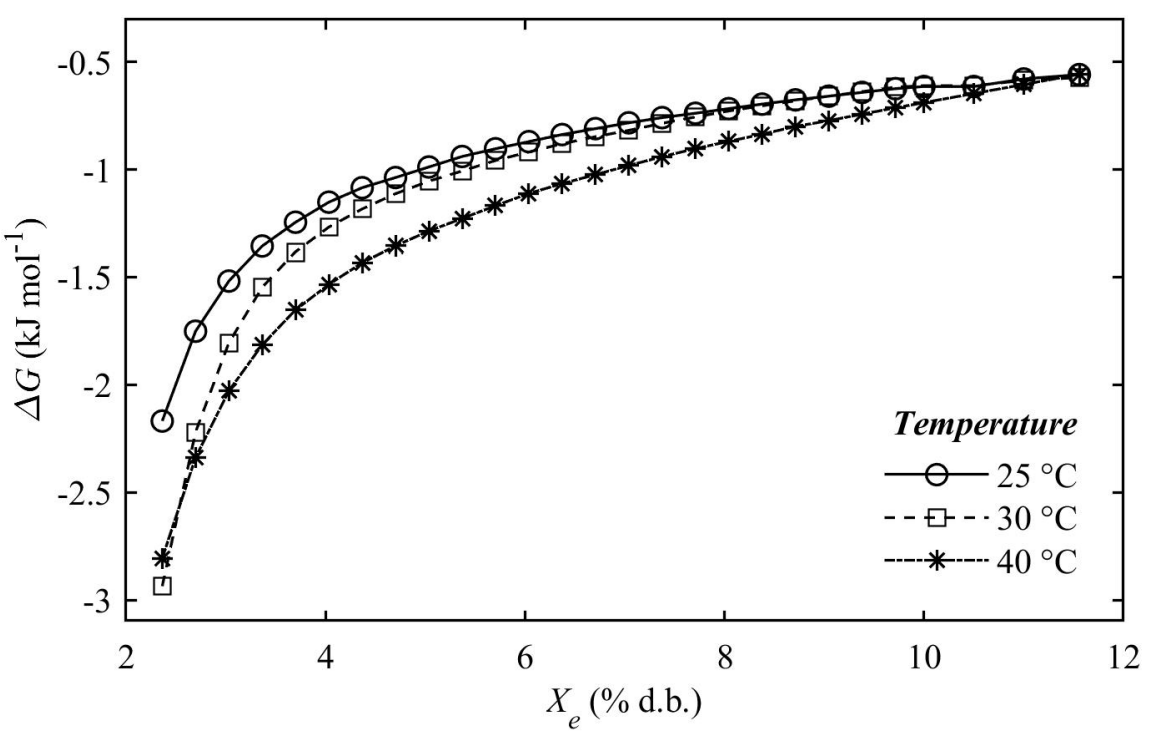

FIGURE 3 - Gibbs free energy of the ground roasted-coffee at temperatures of $25{ }^{\circ} \mathrm{C}, 30{ }^{\circ} \mathrm{C}$ and $40{ }^{\circ} \mathrm{C}$ as a function of the equilibrium moisture content.

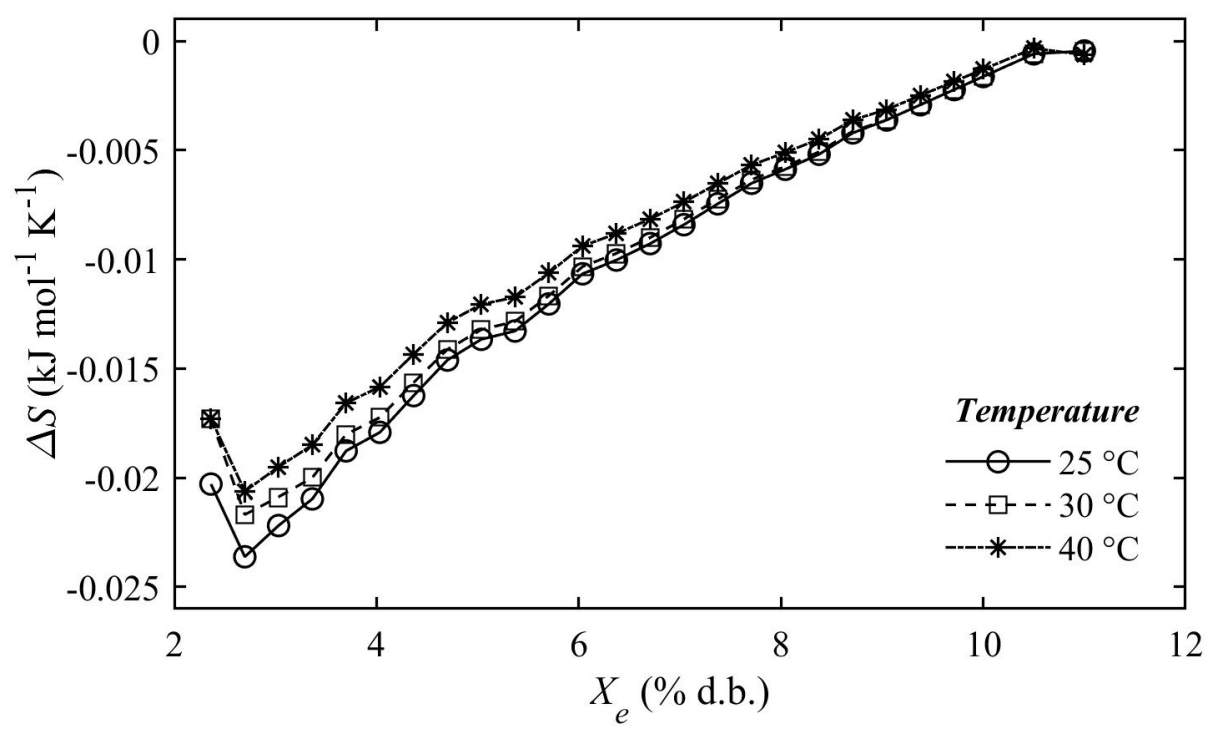

FIGURE 4 - Entropy of adsorption of ground roasted-coffee at temperatures of $25{ }^{\circ} \mathrm{C}, 30^{\circ} \mathrm{C}$ and $40{ }^{\circ} \mathrm{C}$ as a function of the equilibrium moisture content.

The increase of the adsorption entropy indicates the increase in the degrees of freedom of the water in the product, which increased with the equilibrium moisture content; therefore, a less structured system is described. Similar negative values of entropy of adsorption have been reported by OLIVEIRA et al. (2016) in roasted coffee and PROKOPIUK et al. (2010) in algarroba pods.
According to MOREIRA et al. (2016), the minimum values of entropy can be interpreted as the condition at which a product has the best stability. Thus, with the results seen in Figure 4 , it is possible to conclude that the equilibrium moisture content corresponded to a higher order degree of the water molecules in the specialty, ground roasted-coffee $\left(\Delta_{S}<0\right)$ was $X_{e}=2.6 \%$ d.b. 
The Weibull model offers a tool for the prediction of water activity intervals that correspond to the equilibrium moisture content, which evidenced the lowest entropy of adsorption of the system; therefore, it is possible to guarantee the stability of high quality, ground, roasted coffee if stored in environments where the water activity does not exceed 0.5 at temperatures between $25^{\circ} \mathrm{C}$ and $40^{\circ} \mathrm{C}$.

\section{CONCLUSIONS}

The moisture adsorption behavior of the specialty, ground roasted-coffee exhibited the Type III common sigmoid pattern. The adsorption isotherms were modeled with the Weibull model, which proved to be satisfactory for the prediction of the experiment data and can be used to describe the behavior of specialty, ground roasted-coffee (medium roast and medium particle size) during storage conditions with a water activity interval between 0.1 and 0.8 and temperatures between 25 ${ }^{\circ} \mathrm{C}$ and $40{ }^{\circ} \mathrm{C}$. The adsorption isotherms obtained with the dynamic dewpoint isotherms method (DDI) offered high availability for the experiment points, a broad range of work and great precision, thus eliminating the disturbances associated with the handling and manipulation of samples and the possible phenomenon of mass transfer.

Likewise, the amount of energy released by the water adsorption in the coffee increased as the water content decreased, which was expressed by the net isosteric heat of adsorption, and the Gibbs free energy values showed that the water adsorption was a spontaneous process. The entropy of adsorption increased with the moisture content and put in showed at to guarantee the stability of high-quality ground roasted coffee, the storage should be in environments where the water activity does not exceed 0.5 at temperatures between $25^{\circ} \mathrm{C}$ and $40{ }^{\circ} \mathrm{C}$.

\section{ACKNOWLEDGMENT}

This work was supported by the South Colombian Coffee Research Center CESURCAFÉ.

\section{REFERENCES}

BAPTESTINI, M. F.; CORRÊA, P. C.; HORTA DE OLIVEIRA, G. H.; CECON, P. R.; SOARES, F. N. D. Kinetic modeling of water sorption by roasted and ground coffee. Acta Scientiarum, Maringá, v. 39, n. 3, p. 273-281, July-Sept., 2017. DOI: $10.4025 /$ actasciagron.v39i3.32576.

BASTIOĞLU, A. Z.; KOÇ, M.; ERTEKIN, F. G. Moisture sorption isotherm of microencapsulated extra virgin olive oil by spray drying. Food Measure, 2017. DOI: $10.1007 / \mathrm{s} 11694-017-9507-4$
BON, J.; VAQUIRO, H. A.; MULET, A. Modeling sorption isotherms and isosteric heat of sorption of Mango pulp cv. tommy atkins. Biotecnología en el Sector Agropecuario y Agroindustrial. Vol 10 No. 2 (34 - 43) 2012. Available on: $<$ http://www.scielo.org.co/scielo.php?script $=$ sci arttext\&pid=S1692-35612012000200005>. Access in: 21 oct. 2018.

BONNER, I. J.; KENNEY, K. L. Moisture sorption characteristics and modeling of energy sorghum (Sorghum bicolor L.) Moench. Journal of Stored Products Research, 2013. DOI: http://dx.doi. org/10.1016/j.jspr.2012.11.002

BORÉM, F. M.; RIBEIRO, C. F.; FIGUEIREDO, P. L.; GIOMO, G. S.; FORTUNATO, V. A.; ISQUIERDO, E. P. Evaluation of the sensory and color quality of coffee beans stored in hermetic packaging, Journal of Stored Products Research, 2013. http://dx.doi.org/10.1016/j. jspr.2012.08.004

BRUNAUER, S.; DEMING, S. L.; DEMING, E. W.; TELLER, E. On a theory of the Van der Waals Adsorption of Gases. J. Am. Chem. Soc, 1940. DOI: $10.1021 / \mathrm{ja} 01864 \mathrm{a} 025$

CABALLERO-CERÓN, C.; SERMENT-MORENO, V.; VELAZQUEZ, G.; TORRES, J. A.; WELTICHANES, J. Hygroscopic properties and glass transition of dehydrated Mango, apple and Banana. J Food Sci Technol, 2017. DOI: https://doi.org/10.1007/ s13197-017-2963-3

CANO-HIGUITA, D. M.; VILLA-VÉLEZ, H. A.; TELIS-ROMERO, J.; VÁQUIRO, H. A.; NICOLETTI, T. V. R. Influence of alternative drying aids on watersorption of spray dried mango mix powders: A thermodynamic approach. Food and Bioproducts Processing 93 (2015) 19-28, 2015. DOI: http://dx.doi. org/10.1016/j.fbp.2013.10.005

ČERVENKA, L.; HLOUŠKOVÁ, L.; ŽABČÍKOVÁ, S. Moisture adsorption isotherms and thermodynamic properties of green and roasted Yerba mate (Ilex paraguariensis). Food Bioscience, 2015. https://doi. org/10.1016/j.fbio.2015.10.001

CORRÊA, P. C.; GONELI, L. A.; JUNIOR, A.; OLIVEIRA, H. G.; VALENTE, D. Moisture sorption isotherms and isosteric heat of sorption of coffee in different processing levels. International Journal of Food Science and Technology, 2010. DOI: 10.1111/j.1365-2621.2010.02373.x 
DI DONFRANCESCO, B.; GUTIERREZ-GUZMAN, N.; CHAMBERS, E. Comparison of results from cupping and descriptive sensory analysis of colombian brewed coffee. Journal of Sensory Studies, 2014. DOI:10.1111/joss.12104

DOMIAN, E.; BRYNDA-KOPYTOWSKA, A.; CIESLA, J.; GÓRSKA, A. Effect of carbohydrate type on the DVS isotherm-induced phase transitions in spray-dried fat-filled pea protein-based powders. Journal of Food Engineering, 2018. DOI: https://doi. org/10.1016/j.jfoodeng.2017.11.012

EIM, V. S.; ROSSELLO, C.; FEMENIA, A.; SIMAL, S. Moisture Sorption Isotherms and Thermodynamic Properties of Carrot. International Journal of Food Engineering, 2011. DOI: 10.2202/1556-3758.1804

FERREIRA DE SOUZA, J. S.; VAQUIRO, H. A; VILLA-VÉLEZ, A. H.; POLACHINI, C. T.; TELISROMERO, J. Physical, Thermal and Water-Sorption Properties of Passion Fruit Seeds. International Journal of Food Engineering, 2014. DOI: 10.1515/ ijfe-2014-0138

GARCÍA-PÉREZ, J. V.; CÁRCEL, J. A.; CLEMENTE, G.; MULET, A. Water sorption isotherms for lemon peel at different temperatures and isosteric heats. Swiss Society of Food Science and Technology, 2008. DOI: 10.1016/j.lwt.2007.02.010

HERMAN, C.; SPREUTELS, L.; TUROMZSA, N.; KONAGANO, M. E.; HAUT, B. Convective drying of fermented Amazonian cocoa beans (Theobroma cacao var. Forasteiro). Experiments and mathematical modeling. Food and Bioproducts Processing, v 108, p.81-94, 2018. https://doi.org/10.1016/j. fbp.2018.01.002

IACCHERI, E.; LAGHI, L.; CEVOLI, C.; BERARDINELLI, A.; RAGNI, L.; ROMANI, S.; ROCCULI, P. Different analytical approaches for the study of water features in green and roasted coffee beans. Journal of Food Engineering, 2015. DOI: https://doi.org/10.1016/j.jfoodeng.2014.08.016

KHAWAS, P.; CHANDRA, D. S. Moisture sorption isotherm of underutilized culinary banana flour and its antioxidant stability during storage. Journal of Food Processing and Preservation, 2016. DOI:10.1111/ jfpp. 13087

KREUML, M. T. L.; MAJCHRZAK, D.; PLOEDERL, B.; KOENIG, J. Changes in sensory quality characteristics of coffee during storage. Food Science \& Nutrition, 2013. DOI: 10.1002/fsn3.35
LABUZA, P. T.; ALTUNAKAR, B. Water Activity Prediction and Moisture Sorption Isotherms. Water Activity in Foods: Fundamentals and Applications, Chapter 5, 2007. DOI: 10.1002/9780470376454.ch5

MARTÍNEZ-LAS HERAS, R. A.; HEREDIA, M. L.; CASTELLÓ, A. A. Moisture sorption isotherms and isosteric heat of sorption of dry persimmon leaves. Food Bioscience-ScienceDirect, 2014. DOI: http:// dx.doi.org/10.1016/j.fbio.2014.06.002

MOREIRA, R.; CHENLO, F.; SINEIRO, J.; ARUFE, S.; SEXTO, S. Water sorption isotherms and air drying kinetics of fucus vesiculosus brown seaweed. Journal of Food Processing and Preservation, 2016. DOI: 10.1111/jfpp. 12997

MOUSA, W.; MOHAMAD, F.; JINAP, S. G.; MOHD, H.; RADU, S. Sorption isotherms and isosteric heats of sorption of Malaysian paddy. J Food Sci Technol, 2012. DOI: 10.1007/s13197-012-0799-4

OLIVEIRA, G. H.; CORRÊA, P. C.; RODRIGUES DE OLIVEIRA, A. P.; BAPTESTINI, F. M.; VARGASELÍAS, G. A. Roasting, grinding, and storage impact on thermodynamic properties and adsorption isotherms of arabica coffee. Journal of food processing and preservation, 2016. DOI:10.1111/jfpp.12779

ÖZDESTAN, Ö.; VAN RUTH, S. M.; ALEWIJN, M.; KOOT, A.; ROMANO, A.; CAPPELLIN, L.; BIASIOLI, F. Differentiation of specialty coffees by proton transfer reaction-mass spectrometry, Food Research International, 2013. DOI: http://dx.doi. org/10.1016/j.foodres.2013.05.013

PICCINO, S.; BOULANGER, R..; DESCROIX, F.; SING, C. A. S. Aromatic composition and potent odorants of the "specialty coffee" brew "Bourbon Pointu" correlated to its three trade classifications. Food Research International, 2014. DOI: http:// dx.doi.org/10.1016/j.foodres.2013.07.034

PROKOPIUK, D.; MARTÍNEZ-NAVARRETE, N.; ANDRÉS, A.; CHIRALT, A.; CRUZ, G. Influence of Roasting on the Water Sorption Isotherms of Argentinean Algarroba (Prosopis alba Griseb) Pods. International Journal of Food Properties, 2010. DOI: $10.1080 / 10942910902742055$

SCHMIDT, S. J.; LEE, W. J. Comparison Between Water Vapor Sorption Isotherms Obtained Using The New Dynamic Dewpoint Isotherm Method and those Obtained Using The Standard Saturated Salt Slurry Method. International Journal of Food Properties 15(1-2):236-248, 2012. DOI: $10.1080 / 10942911003778014$ 
SHIGEHISA, T.; INOUE, T.; KUMAGAI, $\mathrm{H}$. Matematical model of water sorption isotherms of UBC. Fuel Processing Technology, 2015. DOI: http:// dx.doi.org/10.1016/j.fuproc.2014.11.023

SHITTU,T.A.; IDOWU-ADEBAYO, F.;ADEDOKUN, I. I.; ALADE, O. Water vapor adsorption characteristics of starch-albumen powder and rheological behavior of its paste. Nigerian Food Journal, 2015. DOI: http:// dx.doi.org/10.1016/j.nifoj.2015.04.014

\section{SPECIALTY COFFEE ASSOCIATION OF} AMERICA. SCAA. Protocols: coffee cupping standards. Version Feb. 2018. Available on: $<$ http:// scaa.org $/$ ?page $=$ resources $\& d=$ cupping-standards $>$. Access in: 2 Mar. 2018.

TADAPANENI, R. K.; YANG, R.; CARTER, B.; TANG J. A new method to determine the water activity and the net isosteric heats of sorption for low moisture foods at elevated temperatures. Food Research International, 2017. DOI: http://dx.doi.org/10.1016/j. foodres.2017.09.070

TAPIERO, S. O.; TRUJILLO, B. D.; GUTIÉRREZ G. $\mathrm{N}$. Aplicación del proceso analítico jerárquico ahp para definir la mejor taza en evaluación de cafés especiales, Coffee Science, 2017. DOI: http://dx.doi.org/10.25186/ cs.v12i3.1301

TEIXEIRA, P. L.; T. DE ANDRADE, E.; DEVILLA, A. I. Isosteric heat, entropy, and gibbs free energy of pumpkin seeds (Cucurbita moschata). Engenharia Agrícola, 2018. DOI: http://dx.doi.org/10.1590/18094430-eng.agric.v38n1p97-102/2018
TSAI, S-Y.; HWANG, S-P.; LIN, C-P.; A kinetics study of coffee bean of roasting and storage conditions. Journal of Food Processing and Preservation, 2016. DOI: $10.1111 /$ jfpp. 13040

URIBE, L.; VEGA-GÁLVEZ, A.; DI SCALA, K.; OYANADEL, R.; TORRICO, S. J.; MIRANDA, M. Characteristics of Convective Drying of Pepino Fruit (Solanum muricatum Ait.): Application of Weibull Distribution. Food Bioprocess Technol, 2011. DOI: 10.1007/s11947-009-0230-y

VIGANÓ, J.; AZUARA， E.; TELIS， V. R. N.; BERISTAIN, C. I.; JIMÉNEZ, M. Role of enthalpy and entropy in moisture sorption behavior of pineapple pulp powder produced by different drying methods. Thermochimica Acta, 2012. DOI: 10.1016/j. tca.2011.11.011

VILLA-VELEZ, H. A.; VÁQUIRO, H. A.; BON, J.; TELIS-ROMERO, J. Modelling thermodynamic properties of Banana waste by analytical derivation of desorption isotherms. International Journal of Food Engineering, 2012. DOI: https://doi.org/10.1515/15563758.2191

WEI, F.; TANOKURA, M. Chemical Changes in the Components of Coffee Beans during Roasting-Chapter 10. Coffee in Health and Disease Prevention, 2015. DOI: http://dx.doi.org/10.1016/B978-0-12-4095175.00010-3

YOGENDRARAJAH, P.; SAMAPUNDO, S.; DEVLIEGHERE, F.; DE SAEGER, S.; DE MEULENAER, B. Moisture sorption isotherms and thermodynamic properties of whole black peppercorns (Piper nigrum L.). LWT - Food Science and Technology, 2015. DOI: http://dx.doi.org/10.1016/j. lwt.2015.05.045 